\title{
UŽGAVE்NE்S: A RURAL AND URBAN, RELIGIOUS, SOCIALIST, AND LITHUANIAN FESTIVAL OF SHROVETIDE
}

\author{
Žilvytis ড̌aknys
}

\begin{abstract}
The article uses the case of Užgavenès (Shrovetide) to reveal how the content of a festival can shift over time. It discusses how festival associated with agricultural calendar can acquire a religious character and become a youth, urban, socialist, national, and ethnic festival, can be used not only for recreational purposes but also ideological ones in the fight against religiousness and an attempt to create a socialist festival, and, at the same time, to nurture Lithuanian culture. The newly created image of Užgavènès as a rite of passage - a festival marking a turn of season - has determined its recent fate and even given it greater significance. It has also spread in Lithuanian communities abroad, forming a temporary deterritorialised Lithuanian ethnic cultural space, allowing them to feel 'back at home' in each other's company, and to maintain their ethnic identity.
\end{abstract}

Keywords: ethnic identity, festival, ideology, Lithuania, religion, socialism, Užgavènès (Shrovetide)

\section{INTRODUCTION}

In the Republic of Lithuania the day of Užgavènès (Shrove Tuesday ${ }^{1}$ ) is an ordinary working day. Yet, it is also a great festival. This festival is celebrated either on the traditional day (Tuesday) or moved to the preceding weekend (Saturday or Sunday) in different localities throughout Lithuania. Mass events already start on Saturday. For example, in Vilnius in 2013, the Vilnius Ethnic Culture Centre organised an Užgavènès celebration based on the tradition of the Samogitian ethnographic region ${ }^{2}$. The following description was presented in the event's programme:

The merry uproar of costumed processioners in the city of Vilnius begins already during the day. At about nightfall, the masked characters - a Bear, a Crane, a Rider on a horse, a Death, a Goat, and a Doctor, as well as Gypsies $^{3}$, Hungarians ${ }^{4}$ Jews $^{5}$, beggars, devils, witches, Lašininis (Porky) ${ }^{6}$ struggling with Kanapinis (Hempen Man) ${ }^{7}$ and Morè, which is the spirit 
of the devilish, overstayed winter, and is borne on a runner or a wheel, gather to burn the symbolic effigy of More ${ }^{8}$ and drive out winter. When all of the masked processioners, squealing with joy around a bonfire, burn More and coloured flames shoot into the sky announcing the end of winter, Kanapinis wins the struggle with Lašininis and 'drives him out' until Easter. A great deal of fatty and filling food and traditional pancakes ${ }^{9}$, symbolising the primeval sacrifice of bread, are eaten during the festival. (Užgavènès Vilniuje! Renginių programa)

The actual Užgavènès day (Tuesday) is much quieter, yet many festival events take place and the city abounds in masked children and adolescents. Children also celebrate at schools. In 2013 even the President of the Republic of Lithuania, Dalia Grybauskaitè, visited one of the festival events and met pupils of Žvèrynas Gymnasium on this day. The country leader watched the battle between Lašininis and Kanapinis, set the effigy of Morè on fire, danced national dances, and tasted traditional pancakes (Prezidentè D. Grybauskaitè 2013).

Traditionally, the people returning from work at about sundown receive unexpected guests: several groups of costumed, masked, or painted children and adolescents chanting the traditional formula: "We, Gypsies (or Jews) of Lithuania, request pancakes and coffee; if you have no pancakes, please dig out some money". Children are usually cheered to receive several coins but are also satisfied with sweets, fruits, or pancakes. The festival is celebrated in a similar manner all over Lithuania.

The Open Air Museum of Lithuania in Rumšiškès, which is called the Užgavènès Capital, attracts the most participants. ${ }^{10}$ In general, this festival has a far less commercial nature in Lithuania than Christmas, Easter, or Midsummer, but it is still celebrated wholeheartedly, not only by the inhabitants of Lithuania and foreign tourists (especially young people), but also by Lithuanians living abroad.

Considerable significance is attached to Užgavenès in Lithuanian communities abroad: in Ireland, Belarus, Belgium, Canada, Denmark, Estonia, Greece, Spain, the United Kingdom, the United States, Canada, Latvia, Poland, Luxemburg, France, the Russian Federation, Finland, Sweden, Switzerland, Ukraine, Hungary, and Germany, i.e., in 22 of the 39 states in which Lithuanian communities officially exist. In these 22 countries Lithuanians celebrate Užgavėnès, often calling it a 'Lithuanian' festival. How did Užgavènès, a festival associated with agricultural calendar, become a festival uniting Lithuanians around the world? This article is an attempt to answer this question and to reveal the transformation of this festival's content over time. 
The main source for this article is materials of ethnographic fieldwork on the ritual year of young people. I also participated in projects, the aim of which was to compile data for an atlas of Lithuanian traditions. The conducted research can be divided into several stages.

During the first stage (1988-1995), about 250 localities were explored by surveying local people born prior to 1920, using the semi-structured interview method. The interviewees were requested to tell about the customs that had existed in their youth. Fieldwork was also undertaken in Lithuanian communities located near the border of the Republic of Lithuania in Poland, Latvia, and Belarus (Šaknys 2001a). During these explorations, data were compiled about the Užgavènès customs in 1910-1940.

During the second investigation stage (2002-2009), young people, most of them aged 16-25, were questioned about the present-day festival, using semistructured interview and observation methods. The fieldwork included 150 localities. Investigations of present-day youth customs were also conducted in Latvia (in 2000 and 2001) and Poland (2005). In an effort to comprehend the specific features of urban culture, investigations of youth customs were also conducted in Lithuanian capital Vilnius in 2005, 2007, 2008, 2012, and 2013. During this fieldwork, data were compiled about the situation in the early 21st century. During the entire fieldwork period, mainly Catholic (Evangelical Lutherans in the west of Lithuania, and Reformed Evangelicals in the northeast) Lithuanians were surveyed. Catholic Poles were frequent interviewees in southeast Lithuania and the city of Vilnius. Small numbers of Russian Old Believers, Belarusian and Russian Orthodox believers, and non-Christians were also interviewed, most of them in Vilnius.

The fieldwork was conducted on one or two-week expeditions with fixed itineraries, and on day trips in the city of Vilnius and in localities at a distance of up to $100 \mathrm{~km}$ from it.

It is fairly difficult to reveal the situation during the Soviet occupation on the basis of these fieldwork data. The creation of the new socialist calendar festivals was rather chaotic. The changing attitudes of the Soviet ideologists towards festivals and local initiatives caused diversity and rapid changes in these festivals. As the festivals that replaced Užgavėnès lacked clear symbols, the reconstructions of the festivals celebrated during the Soviet period, offered by people several decades later, were rather vague. Therefore published sources were mainly used in analysing the Soviet era festivals.

Meanwhile a more comprehensive investigation of the customs of Lithuanian diaspora has only begun; an analysis of the Užgavėnès festival celebrated in Lithuanian communities far from Lithuania is possible by using mainly internet sources. 


\section{UŽGAVĖNĖS, AN AGRICULTURAL FESTIVAL}

In the words of ethnologist Irena Regina Merkienè, traditional calendar rites are a component of agrarian culture. In Lithuania, these rites were affected by Christianity somewhat less than in other European nations and mainly reflect the experience of local farmers, animal breeders, beekeepers, and wild food foragers (Merkienè 2011: 173). The oldest data about Užgavėnès customs in the Balts' territories date back to the 15 th century. At a 1428 sermon, monk Heinrich Berinberger mentioned that in Lower Prussia "devil dances occur [---] during weddings and at Užgavènès, and respectable people allow women to dress in men's clothing, boyish coats, etc., which God has forbidden" (Vèlius 1996: 492). More detailed data about Lithuanian Užgavènès customs are available only from the sources of the 19th and early 20 th centuries. For example, Liudvikas Adomas Jucevičius in his 1842 Žemaičiu žemes prisiminimai (Recollections of the Land of the Samogitians) mentions having seen processions at Užgavènès in his childhood. He describes processioners dressed as Jews, Germans, Gypsies, and soldiers, and a straw figure paraded on a cart on Ash Wednesday and later burnt. According to the author, this ritual was probably performed in ancient times and had some mystical meaning (Jucevičius 1959: 448-449).

As Arūnas Vaicekauskas has noted, Central and Eastern European agricultural folk traditions have many common features. The main rituals of the calendar festivals are no exception. For example, the essential Užgavėnès festival rites in all of the region's cultures include processions of costumed village youths, parades with horse-pulled sledges, dragging around a straw figure or a block of wood, a cornucopia of food positively mandatory for all agricultural rituals, swinging on swings, and other (less meaningful) rites. The structure of the Užgavènès festival is essentially identical everywhere, but even such a comparatively small territory as that occupied by ethnographic Lithuania today has certain regional features: "In the east, southeast, and south of Lithuania the main emphasis of the Užgavènès rites was on riding in horse-drawn sledges, while in Samogitia (and partly in central Lithuania) costumed processions predominated" (Vaicekauskas 2010). A. Vaicekauskas has observed that Užgavènès does not have any feast status in the Catholic liturgical calendar and is today considered an ordinary day before the Lenten fast. Only in the traditional agricultural calendar does Užgavènès have all of the features of a large (annual) festival (Vaicekauskas 2005: 11). On the other hand, the fact that it is the last day before 46 days of abstention from meat and gaiety, has led to the festival's intensity and frequently motivated young people to participate, for one last time, in merry parties, and people of all ages to eat heartily meaty 
foods prior to the fast. For this reason, we cannot claim that Užgavènès festival had no connection with the religious calendar. This influence is not direct and is connected to the structure of the Catholic calendar. Užgavènès has been given similar significance by the Old Believer and Orthodox religions. Nevertheless, this connection with the Christian calendar was a sufficient pretext during the Soviet occupation to call Užgavènès a religious festival.

\section{YOUNG PEOPLE'S UŽGAVĖNĖS}

Besides the adults' community united by age, territory, and common interests, the agricultural society of the late 19th and first half of the 20th centuries featured a community of young people with definite autonomy. While the life of the adult community was connected by common economic ties and work, the territorial community of the young people was joined by leisure and recreation and the need to 'copy' and learn about adult life. The ritual year of the youth community was inseparably connected with agricultural and Christian religious calendars (̌̌aknys 1996: 105-115).

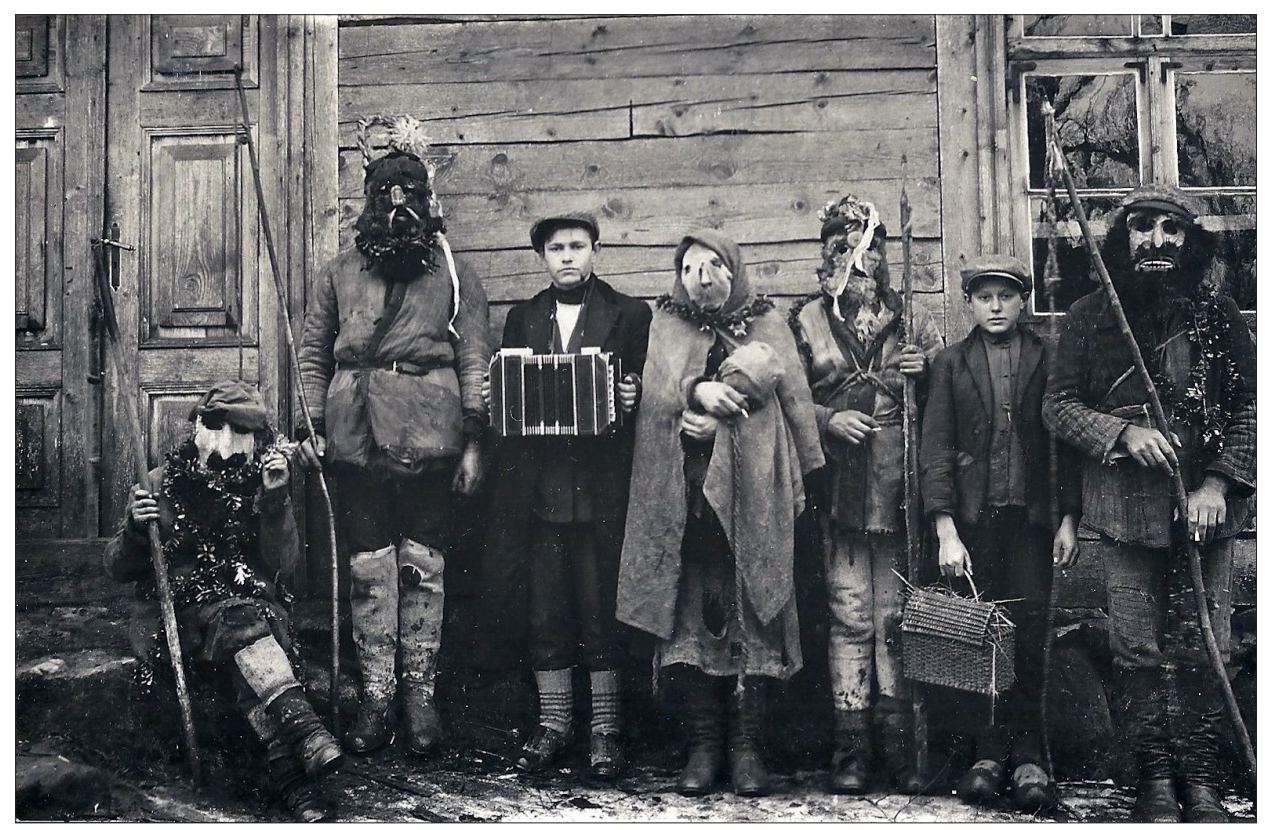

Figure 1a. Masked youth. Salantai, 1923. MFL 949. 
Žilvytis Šaknys

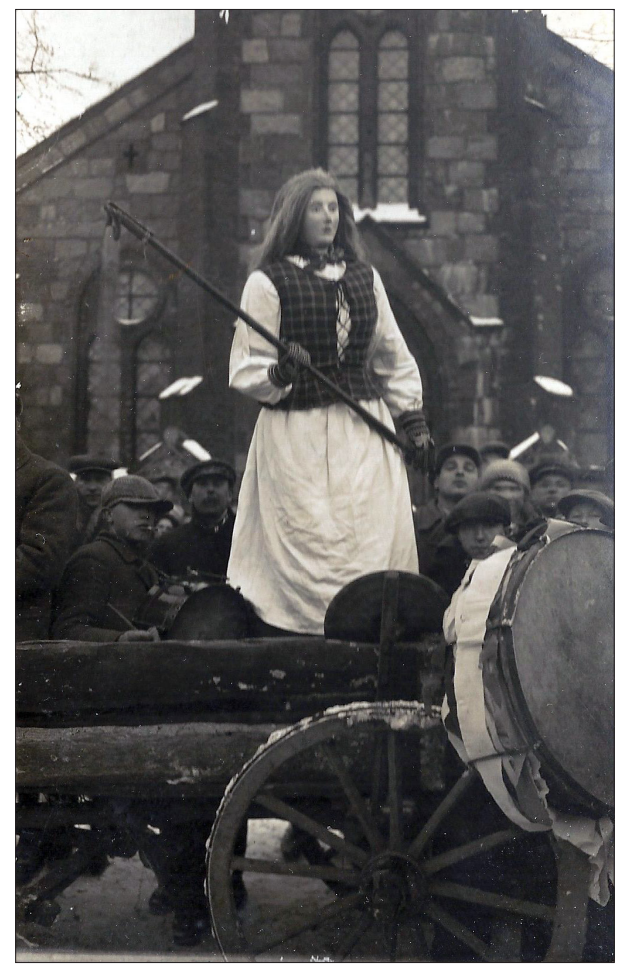

Figure 1b. Moré. Tubausiai, 1932. MFL 949.

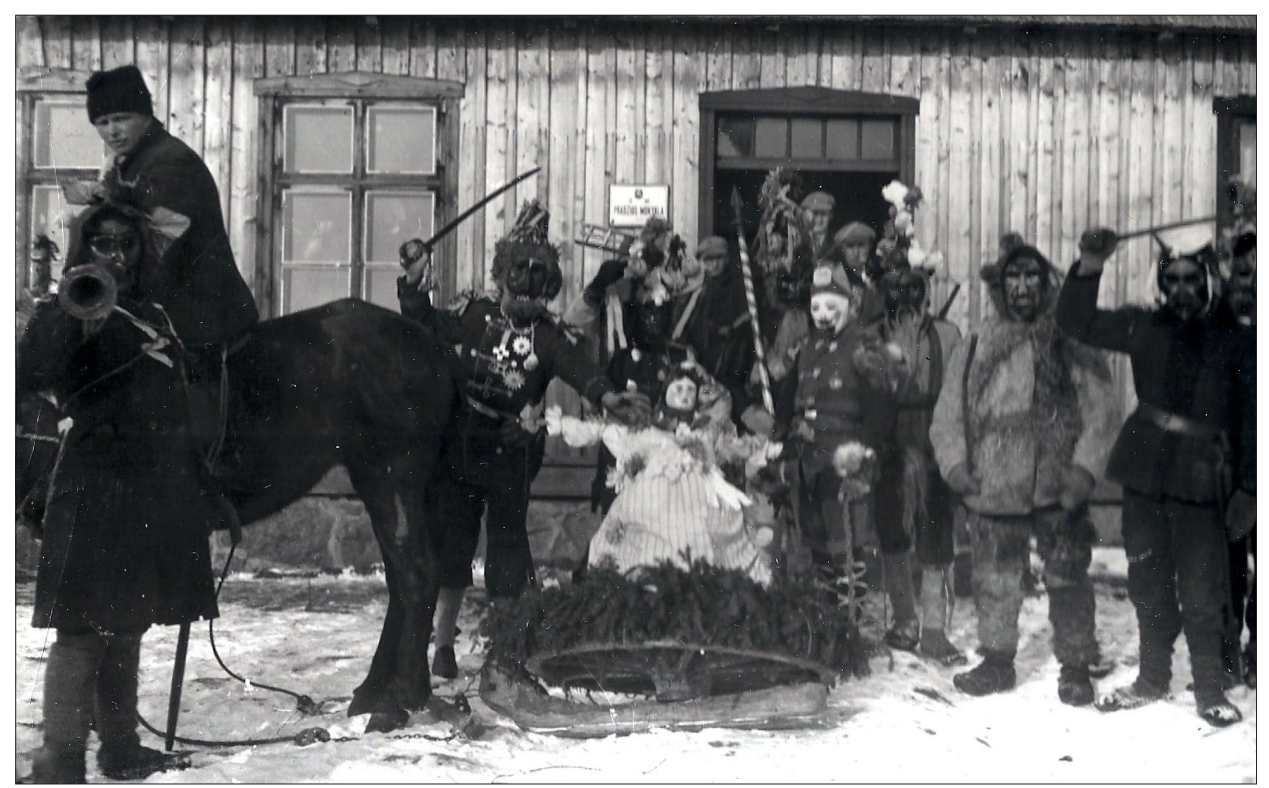

Figure 1c. Masked youth and Morè. Kurmaičiai, Kretinga district, 1933. MFL 949. 
Užgavėnès was a significant day for young people. Throughout almost all of Lithuania it was related to merrymaking. When asked during field research what Užgavenès meant to them, many of the respondents began with the phrase 'It is the last day before Lent', and usually continued by telling about the dances organised on this occasion. In eastern Lithuania they mentioned merry rides in sledges (the longer the slide, the longer the stem of flax next summer); in the west of Lithuania they mentioned costumed processions. Their motivation was to continue the traditions or just have a good time.

During the interwar period, merriment was organised in $76 \%$ of the studied localities. In $6 \%$ of the localities this did not end at the time decreed by the Church. The clock's hands were turned back or a rooster was hidden under a vat (as after midnight Lent began and it was forbidden to dance), and the merriment lasted until predawn. Užgavènès parties dominated in all of the Lithuanian ethnographic regions except Lutheran Lithuania Minor (Šaknys 2001a: 51). Somewhat more frequently festival merriment occurred only during the biggest holidays - Christmas, Easter, and Pentecost - and lasted 2-4 days, but it was organised more frequently at Užgavènès than New Year, Epiphany, Ascension, and Corpus Christi, even though these were public holidays (Šaknys 2001a: 82).

The custom of a costumed procession was connected not only with Užgavènès. In the first half of the 20th century Christmastide costumed processions were more widespread and marked by considerable diversity. A costumed procession at Epiphany was known all across Lithuania, a procession of boys dressed as biblical figures occurred in a specific region in the southwest of Lithuania, and the main role in the costumed processions in a small part of southern Lithuania was performed by a young man dressed as a horse, Šyvis (Silver). The custom of 'walking around like Gypsies' was widespread in northern Lithuania. Užgavėnès costumed processioners dominated in only one ethnographic region, Samogitia, occurring elsewhere in only isolated instances. The main role in these was performed by boys dressed as Jews; sometimes a procession of children acting like beggars was organised on the eve of the festival (Šaknys 2001a: 45, 51).

The experience acquired with age has special significance in an agricultural society and therefore the actions performed by the young people, in the majority of cases, can hardly be associated with important agricultural rituals. It is perhaps possible to connect the Užgavènès swinging or riding in sledges with these rituals (some of the people knew of the belief that this would improve the flax harvest), but L. Jucevičius, who grew up in Samogitia in the early 19th century (born in 1813) and investigated Samogitian customs in the first half of the century, was already unable to explain the meaning of dressing up in costumes. Respondents born in the late 19th and early 20 th centuries mentioned to only the recreational meaning. From the investigator's perspective it is possible to 


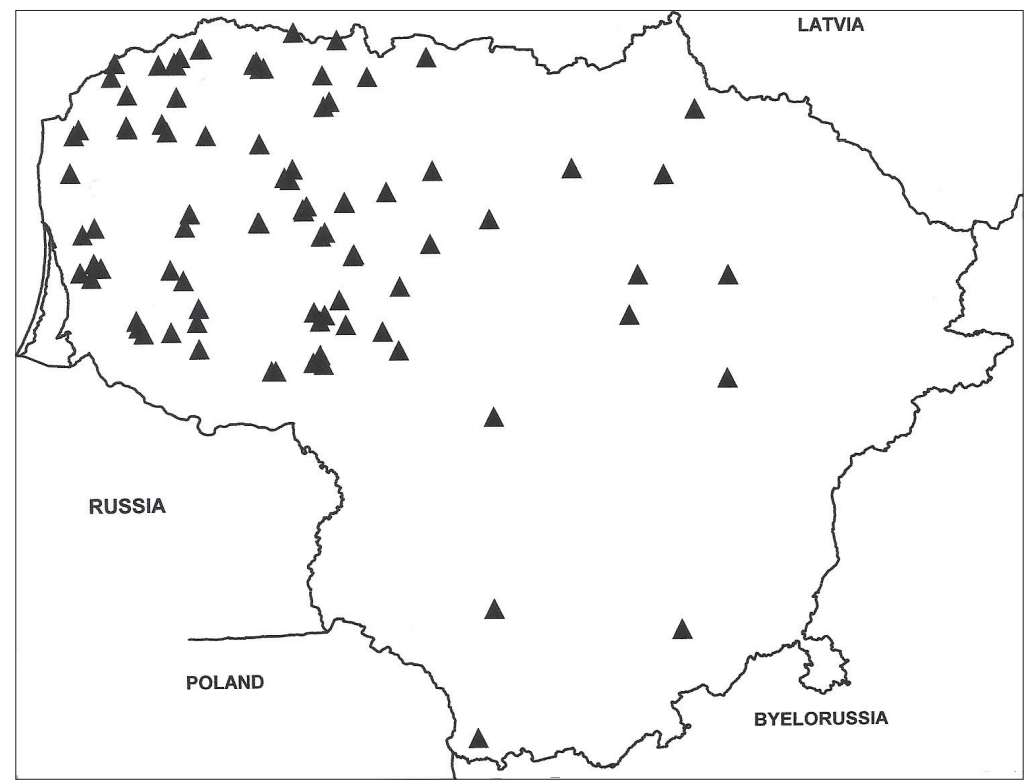

Figure 2. Youth outdoor fete at Užgavėnès (1920-1940) (Šaknys 2001a: 51).

reconstruct the ritual behaviour of the Užgavènès costumed processioners as paying special attention to girls. Like in other Western European countries, the Samogitian costumed processioners went to 'buy spinsters and barren women' (Lith. bergždininké, literally a barren animal), tested how fat they were, forced them to kiss the ground through their apron, jokingly sprinkled them with 'holy water', 'incensed' them with smoke from a pot with embers, jabbed their hands with a nail or used a needle affixed in a mask, etc. (Balys 1993: 50-56). It is also difficult to explain how older people during the interwar period tolerated the abuse that these girls experienced. Genovaitè Jacénaitè described it as follows:

It is better today not to get mad even if the 'Jews' (costumed processioners Ž.Š.) play a practical joke: unleashing the cattle or letting the piglets loose, breaking a jar, pouring milk into the swill, or pouring water into wooden shoes. Better to laugh off everything and even give the pranksters a treat. It could be even worse. I have heard of even greater losses: someone entering a kitchen and tossing a dead crow or rat into the soup, immersing a dungy hobble or wooden shoe into the cream, pushing the housewife into a basket full of eggs, throwing the bucket, sometimes full of milk, into the well... (Jacènaitè 1992: 11) 
To summarise, it is possible to state that during 1920-1940, Užgavènès was already perceived by young people as recreation and relaxation before Lent. In the Lenten period the activities of the youth community were the least intensive of the year in western Lithuania.

\section{URBAN UŽGAVĖNĖS IN THE FIRST HALF OF THE 20TH CENTURY}

A question arises as to how Užgavènès was celebrated in the large cities where the festival had little connection with the agricultural calendar. According to L. Jucevičius, the costumed processions of Užgavènès in the early 19th century were similar to urban masked balls (Jucevičius 1959: 448). As mentioned by Lina Petrošienè, by the 20th century there were already two different, yet interacting traditions: the local-type celebration in rural areas and the imported European-type celebration in noble estates and among city-dwellers (Petrošienè 2013: 14-21). Nevertheless, the urban ritual year was not dissociated from the religious calendar. According to Laima Laučkaitè, the number of celebrations that were connected with the recreational culture born of capitalism, rather than with religion, increased in Vilnius in the early 20th century. The new merriments strictly conformed to the traditional Christian calendar, which in Vilnius dictated a specific recreational rhythm. Public recreation and merriment could not occur during the Orthodox Lenten period (Vilnius at that time being part of the Russian Empire) (Laučkaitè 2008: 472-473). Also there are data that in Vilnius, in the late 19th to early 20th century, women dressed as men and men as women, and visited the homes of the people they knew. Like in villages, people used to eat 6, 7, 9, or 12 times, and pancakes, doughnuts, dumplings, angel wings (sweet crisp pastry), and large quantities of meat were prepared (Znamierowska-Prüfferowa 2009: 162).

But the Užgavėnès of the students in the temporary capital of Lithuania ${ }^{11}$ stands out. A good example of it was the festivity organised by the Student Riflemen's Union in 1936. A gigantic straw effigy of Morè was carted around. In addition to the traditional characters, there were clowns and the straw figure's guard, Kiaulinskis (Pig) ${ }^{12}$. At the Pienocentras (milk processing company) building the clowns 'milked a goat' and 'treated' the nearby people to warm milk (Budreckas 1936: 4). Although the press called the festival participants clowns, this Užgavènès was the first step in holding a Lithuanian Užgavènès in the city. Later on the festival gradually began to spread in the smaller cities of Samogitia (Kudirka 1992: 4). The former agricultural festival was reconstructed in the city and acquired new features. 


\section{THE CONSTRUCTION OF A SOVIET FESTIVAL}

The first post-revolutionary years in Russia showed that elements of traditional calendar festivals could be successfully used for ideological purposes. An important ritual element of the festival was a costumed procession, which is superbly illustrated by the case of Izhevsk (Udmurt Republic, Russia) presented by Maxim Blinov. The main roles in the 1923 carnival were performed by people wearing masks portraying Orthodox, Catholic, Muslim, and Jewish clergymen, and straw figures representing these religions were also carried. After stopping near an Orthodox church, a person in an Orthodox priest's costume began to conduct a mass. Near the executive committee building, a Komsomol member read an announcement, proving the 'pagan' origin of the Christmas festival. Upon completion, the religious straw figures were burnt to the accompaniment of the Internationale (Blinov 2013: 133-134).

Lithuania was under the Communist regime in 1940-1941 and then again in 1944-1990. The first years of the Soviet rule featured mass deportations and a partisan war, and it was not a favourable time to celebrate. On the other hand, the local party figures monitored even innocent attempts to continue former traditions. Užgavènès was regarded as a religious festival and therefore opposed (Kudirka 1992: 4). For example, in western Lithuania, around 1950, those who cooked and ate pancakes during this festival received lower marks for behaviour at school. Young people were also forced to have their hair cut short and go to dances every Saturday throughout the entire Lenten period (Mickevičius 2008: 399). This way the authorities fought against the Catholic traditions forbidding merriment during the Lenten season. Besides denying and banning the old religious festivals during the first years of the Soviet occupation, an attempt was made to create socialist festivals with nothing in common with the traditional ones. As this idea failed, the authorities decided to take advantage of the old festivals by giving them a 'socialist content'. Merriment was encouraged during the Lenten period in another manner, i.e., by holding a winter festival, which replaced Užgavėnès.

In about 1957-1958, Užgavènès began to be revived. It was decided to celebrate the festival in early March (during Lent); mask sketches were ordered, and a famous composer wrote a song for this purpose (Kudirka 1992: 4). A methodical publication Užgavenès - žiemos šventè (Shrove Tuesday - Winter Festival) was published in 1959. It presented recommendations, based on the Samogitian Užgavènès example of how it was possible to adapt this festival to the new traditions of Soviet life (Užgavènès 1959: 1-11). In 1961, regional differences were also examined in the new Užgavènès festival described in the 
methodical publication Naujo gyvenimo tradicijos (New Traditions of Life). A traditional three-meter-high effigy of Morè with a broom and a whip appeared during the winter festival in the vicinity of Pakruojis (north Lithuania). The main goal of the costumed procession was fight against the evil. The traditional symbol of mesédas, the obese Lašininis, was accompanied by bribe takers, profiteers, bureaucrats, bootleggers, and kid-gloved ladies. Meanwhile the escort of Kanapinis, the embodiment of the Lenten period, was formed by traditional characters: a bear, a crane, and clowns. The carnival participants collected carelessly placed objects and the owners had to redeem them with pancakes. After that Lašininis was tried. During visits to various establishments, good workers were praised and slackers rebuked (Černeckis 1961: 9). Morè (the symbol of not only the end of winter, but also of the extermination of all kinds of maladies, evils, and deficiencies) was also burnt in the city of Klaipèda (western Lithuania). But the traditionally lean Kanapinis of the city inhabitants was now pudgy. An ideological explanation was even given: previously, during the fast, Kanapinis had dried out greatly and slimmed down since he had always been very pious and strictly obeyed the church's instructions. Now he had changed completely. Kanapinis no longer believed in religious superstitions and did not keep the fast. On the contrary, he had become an active fighter against everything that was old and obsolete. This positive character sternly criticised the city's evils, and a big tub with idlers, bootleggers, profiteers, and bureaucrats was hitched to the car carrying Kanapinis (ibid.: 8-9). In explaining the festival's origin, the initiator of this Užgavènès festival identified it with the pre-Christian celebration of the spring equinox, which had been moved to Užgavènès after the introduction of Christianity (ibid.: 10).

Although according to Stasys Skrodenis, 1958 was the last year of a real Užgavènès (Skrodenis 2010: 36), in places in Samogitia the traditional Užgavènès still exists (cf. Andriuškevičius 1969: 224-227; Olechnovičienè 2008: 121).

The Winter's Farewell Festival (Lith. Žiemos palydu šventè) more similar to the traditional festival attracted people. In 1977, the Open Air Museum of Lithuania in Rumšiškès began to promote this event. In 1980, the unchanging festival date was set on the last Saturday in February (in fact, even in this case the festival was usually celebrated during Lent). The festival attracted tens of thousands of spectators and tens of folklore ensembles. Although the festival in Rumšiškès levelled the festival's regional differences, according to ethnologist Juozas Kudirka, the festival encouraged people to take an interest in customs as something valuable (Kudirka 1992: 4). Užgavènès, renamed 'Winter's Farewell', the authentic masks, and the cry 'Winter, winter, flee our courtyard!' chanted by thousands of people has gradually given it the features of a 'pre-Christian' 
winter-end ritual, granting it the value of a festival marking the change of seasons. This has caused the festival's success and its rapid spread in Lithuania.

In 1959, the Spring Festival, which was to replace Easter, with the main role played by Old Man Cold, who symbolised the winter period and handed the keys over to Young Man Spring, began to be celebrated (Vyšniauskaitė 1964: 554-556). But this festival did not embody the symbols of the changing of the seasons and did not become established; nor did the Harvest Festival carnival organised in September-October (ibid.: 556-558). These newly created festivals disappeared whereas Užgavènès survived. A festival that evokes no connection with any tradition, as has been mentioned by Catherine Bell, is apt to be found anomalous, inauthentic or unsatisfying by most people (Bell 1997: 45).

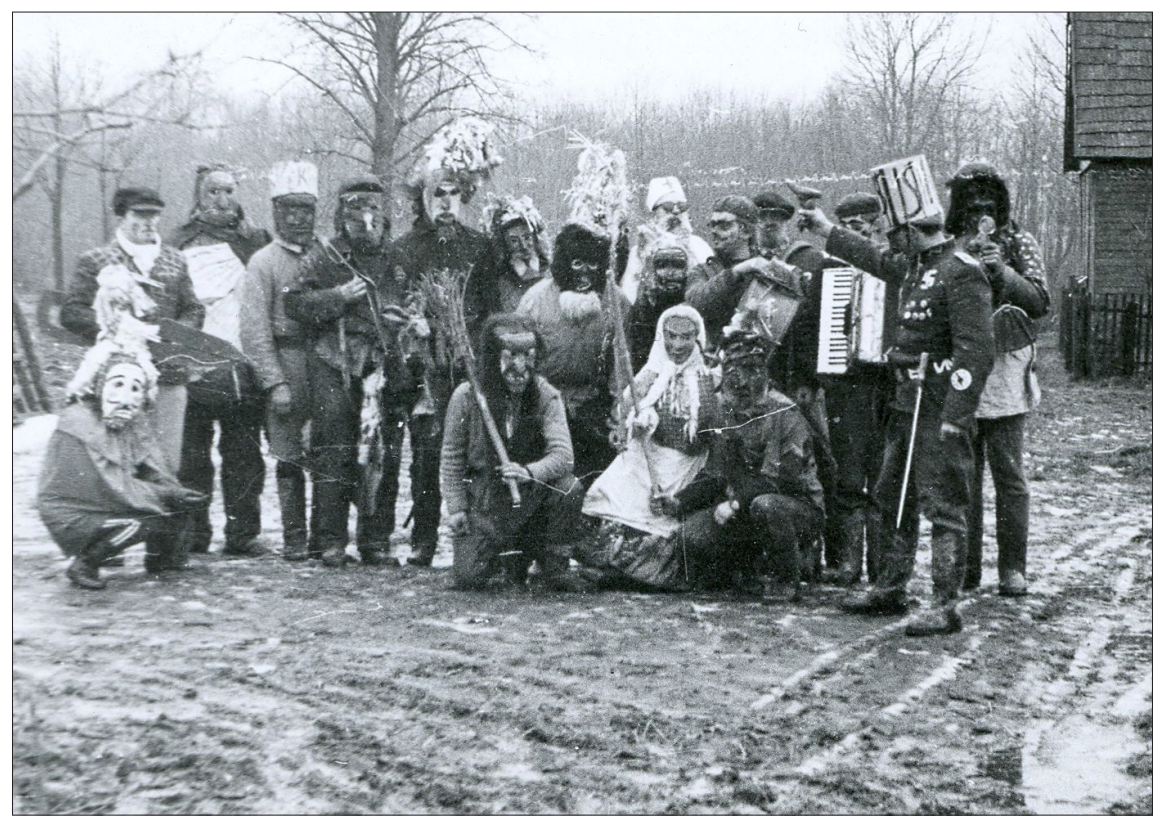

Figure 3. Užgavènès. Plateliai, Plungè district. Photograph by Juozas Mickevičius 1973. MFL, photographic negative No. 80111. 


\section{UŽGAVĖNĖS IN THE 21ST-CENTURY LITHUANIA}

During the years 1988-1990, attention greatly focused on the rejuvenation of pre-Soviet calendar festivals. Rarely did a newspaper or journal, radio station or television channel not recall the 'traditional' Užgavènès customs in an article or programme. This rejuvenation process was actively encouraged. In 1992, books devoted to this festival were published by ethnologists Juozas Kudirka and Inga Krikščiūnienè. A methodical publication in 1996 instructed readers on how to revitalise the festival using ethnographic and folklore material from local people, compiled on site, and to awaken the memory of older people during the festival (Kudirka 1996). However, this practice is not justified in the case of Užgavenès. In many Lithuanian localities this festival is based on slightly adjusted Užgavėnès programmes created during the Soviet era. As is shown by fieldwork in 150 Lithuanian villages and towns, in the 21st century Užgavènès costume customs predominate (masked processions on other traditional occasions - for example, Epiphany - are rare and only isolated instances of other traditional costumed groups have been recorded). Similar to the Soviet era, the festival is frequently celebrated on the weekend, but without moving it into the Lenten period, and the costumed figures devised during the Soviet era are rejected. The Soviet festival was widespread throughout Lithuania. Yet, field research revealed different assessments of the Užgavènès festival in the Lithuanian countryside and cities. Some people think that a real festival should be held on a day off; some (e.g. schoolchildren) think that it is an important festival. Festival mood predominates during classes at schools, and some of them, especially at primary school, are conducted only formally. The opportunity to participate in a costumed procession, an evening dance or a party organised in a group of friends, and/or the town's festival events, live music, and an Užgavènès bonfire make an ordinary school day seem like a holiday. As is seen in Figure 4, almost everywhere in Lithuania events are organised on the occasion of Užgavènès and bonfires are lit to drive out winter (Šaknys 2007: 86).

Young people in south Lithuania organise mainly recreational evenings (Šaknys 2012: 101). Costumed processions of young people (aged 14 and older) are also popular in this part of Lithuania. In other ethnographic regions, only groups of younger children usually parade in costumes (Šaknys 2007: 86; 2009: 80; 2012: 102).

Field research shows that costumed processions participated by girls only or jointly by girls and boys currently prevail. A somewhat different situation exists only in Samogitia, where in some places the processions take place on two days, the first one being called the beggars' day and the second one the Jews' day. On the first day, only children parade in costumes, on the second day young people 


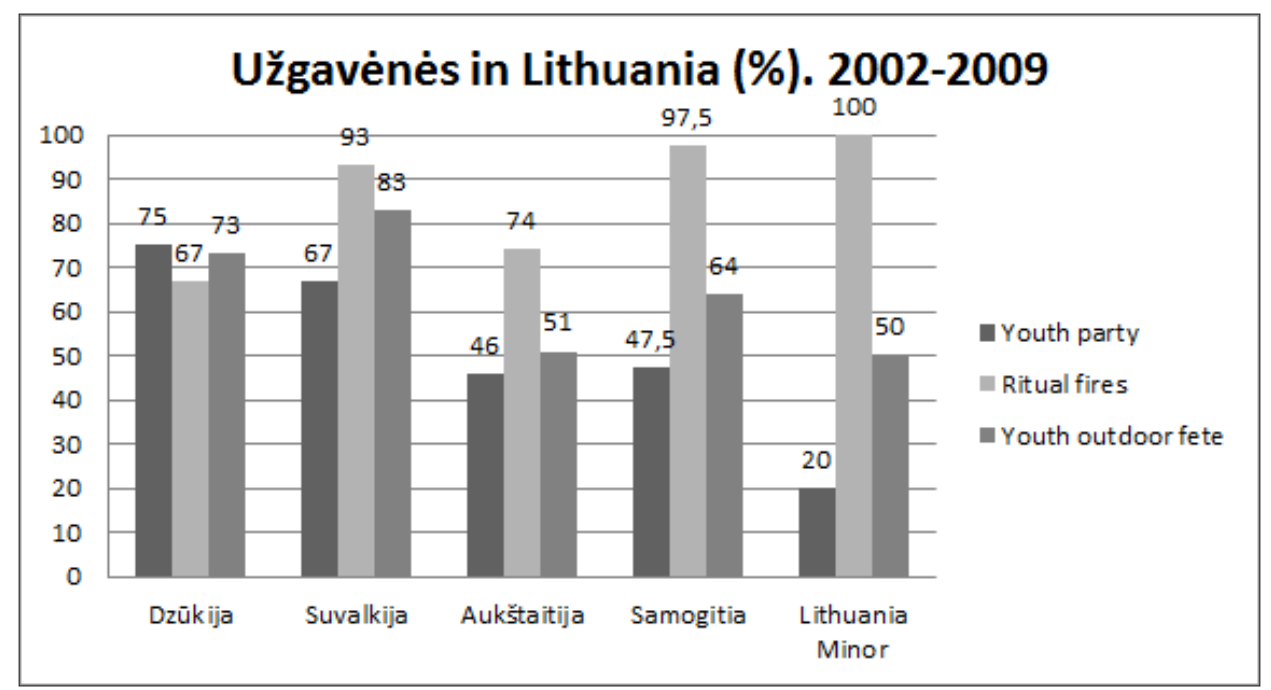

Figure 4. Youth activity at Užgavenès in different parts of Lithuania (2002-2009) (data from Šaknys 2007: 86; Šaknys 2009: 80; Šaknys 2012: 101-102).

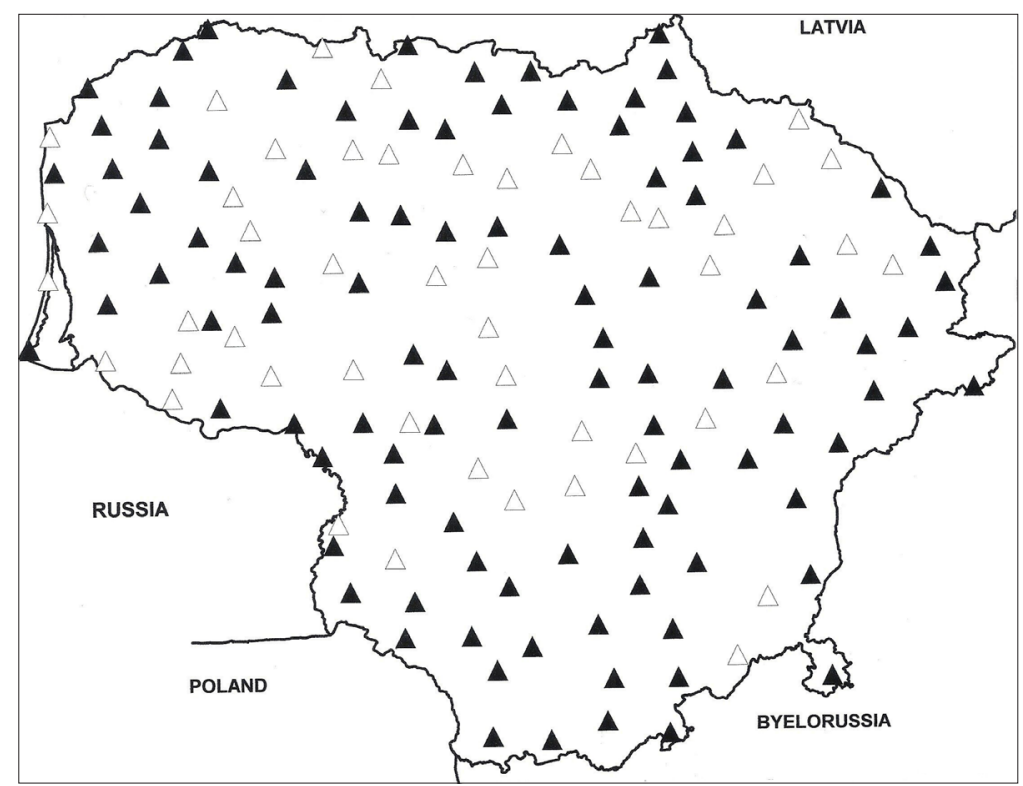

Figure 5. $\Delta$ Youth and children's outdoor fetes at Užgavènè; $\triangle$ Children's outdoor fetes at Užgavenès (2002-2009) (data from: Šaknys 2007: 107; Šaknys 2009: 99; Šaknys 2012: 125). 
and adults. In Grūšlaukè, for example, on the first day 6-13-year-old 'little beggars' and on the second day 15-24-year-old 'Jews' parade. Somewhat differently than in the majority of the localities in Lithuania, the boys are more active in this area (Šaknys 2012: 93). A similar situation can also be seen in Vilnius, where the costumed processions have acquired a commercial character. For example, according to one respondent, they used to dress up as Jews, Gypsies, and devils at Užgavènès. In groups of six they visited bars and cafes, promising 'to drive out winter' in exchange for gifts. They used to be rewarded with sweets and money. When comparing young people's costume customs in the provinces and in the capital, we can say that they are more diverse in Vilnius, where they are not concentrated on only Užgavènès, but also encompass other traditions and modern festivals. According to as much as a third of Vilnius residents, carnivals are also organised on Halloween. Many Vilnius residents are also attracted to the Epiphany festival organised by the Vilnius Ethnic Culture Centre, and they go to fancy dress or theme parties during Christmas and New Year and even on St. Valentine's Day (Šaknys 2013: 103-106). According to A. Vaicekauskas, Lithuania is distinguished from the rest of the Baltic region by its surviving traditional style costumed figures. In fact, modern Western popular culture tendencies can also be encountered (Vaicekauskas 2013: 48-56). Užgavènès is spreading beyond Lithuanian borders, but is being called a Lithuanian festival rather than a boundary festival marking the change in seasons or the driving out of winter.

\section{THE SPREAD OF UŽGAVĖNĖS BEYOND LITHUANIAN BORDERS}

The analysis of the situation in the late 19th and early 20th centuries reveals that Užgavenès costume parade customs were also known in the neighbouring lands: in the present-day territories of Latvia (Olupe 1992: 87-92), Belarus (Kukharonak 2001: 78-80) and Poland (Drożdż 2002: 285-289). However, Užgavenès costume customs were not known in the areas of these countries that bordered on present-day Lithuania. This allowed the Lithuanians of these states who were living in the border areas to perceive these Užgavenès customs as 'Lithuanian', and the local non-Lithuanian inhabitants to recognise their Lithuanian nature.

The largest Lithuanian community close to Lithuanian border is in the vicinity of Punskas (Puńsk) in northeast Poland. According to the recollections of Aldona Vaicekauskienè, in 1981, the ethnographic club of Puńsk School and 
the Lithuanian Society culture club of Puńsk Lyceum organised an Užgavènès festival with a costumed procession, riding in sledges, a bonfire, traditional food, and dancing (Vaicekauskienè 1996a: 177-182). Thus another 'Lithuanian' symbol, i.e., dressing up in costumes, was added to this region's traditional Užgavènès customs of dancing and sledge-riding. In 1985 an attempt was made through the ethnographic club to recreate a theatricalised Užgavènès festival. The pupils were encouraged to appear at the Węgorzewo Spring Festival, where calendar customs from different areas of Poland were presented. They modelled the performance of Samogitian traditions ${ }^{13}$, which they had become acquainted with in Lithuania. According to A. Vaicekauskienè, young people keen on ethnography had come from Lithuania through the club's efforts and had taught the local population new folk dances and games. One of the club members had also had an opportunity to become acquainted with Lithuanian folklore in Lithuania. After returning home she taught the local young people in Puńsk Lithuanian songs, dances, and games (Vaicekauskienè 1996b: 158). Thus the Soviet era Užgavènès became a festival of the Lithuanian diaspora in Poland.

The custom of masking on Užgavènès could not have been so easily established in the Lithuanian community in southeast Latvia since costumed Christmastide processions occurred in this part of Latvia and in the northeast of Lithuania bordering it, but in the late 20th century Lithuanian Užgavènès costume customs started to take root in this region (Šaknys 2001b: 236, 241). Later on this custom migrated to the Lithuanian villages in the vicinity of Gervèčiai (Gervyaty) village in western Belarus. Fairly archaic customs have survived in the villages that have not separated into isolated farmsteads. Yet, Lithuanian Užgavènès began to spread there as well (2011 and 2012 field research data).

The Užgavėnès programmes are somewhat different in the Lithuanian communities in the countries that do not border on Lithuania. However, they are united by a common feature. Užgavènès is becoming 'Lithuanian' only in a polyethnic environment where no festival of a similar nature is celebrated. As Jeremy Boissevain has noted:

One of the most traditional and effective ways to stress the identity of a group is to celebrate a fète or ritual together. In doing so, one can feel 'at home' among each other. One creates a 'face' vis-à-vis other groups. The celebration of festivals is not only a reflection of one's own identity; it is at the same time the model for the manifestation of an identity. (cited in Van Ginkel 2007: 37) 
The internet sources and interviews show that the festivals are organised by the embassy staff, members of the Lithuanian community, foreign Lithuanian youth organisations, the teachers at Lithuanian language Saturday schools, or simply groups of friends. In some cases exceptional significance is attached to Užgavènès. For example, the Lithuanian organisation in Tallinn, Estonia (Šimkute 2012), the Lithuanian organisation Židinys (Hearth) in Moscow, and the Lithuanian Šaltinèlis (Wellspring) Gymnasium in Moscow celebrate only three festivals: Christmas, Easter, and Užgavėnès (Rusijos Lietuviu Bendruomenių Sajunga). Saule Lithuanian language school in Stockholm celebrates Lithuanian Independence Day (February 16), Christmas, Užgavėnės, and Easter (Lietuvių Bendruomenè Švedijoje).

Užgavėnès is already being organised by using modern means. For example, the Lithuanian Youth Union SILTA in Finland organised the festival in Helsinki. Especially for this occasion, the organisers created a Facebook page titled 'Užgavènès', where they invited people to come to Alppipuisto Park in Helsinki on February 10, 2013. Young people decorated a tree with the colours of the Lithuanian flag (as they did not have a big flag). About 20 people assembled. Lithuanians living in Finland came not only with their children, but also with their non-Lithuanian spouses. The participants brought pancakes, cakes, crackers, homemade jam, tea, and coffee. Some also brought Užgavėnès masks they had made. A competition between Kanapinis and Lašininis teams was planned at the festival. Children rode on sleds and other sliding devices. There were snow carrying and tug-of-war competitions and later a mini-Morè was burnt. One of the festival participants described the Užgavènès celebration during an interview. When asked why Užgavènès had been selected, the interviewee answered:

We selected Užgavenès because it is a very pleasant and interesting Lithuanian [emphasis mine - Ž.Š.] festival during a fairly dreary time of the year. It was also an excellent occasion for everyone to meet and do something together. Do we miss our homeland? Perhaps. Although we do not live far from Lithuania and visit our homeland fairly frequently, we miss the language as well as 'our faces', food, and humour. Both the SILTA youth union and the Lithuanian community in Finland actively organise various meetings and events, through which they encourage the preservation of their Lithuanian traditions and promote interaction among Lithuanians. We are all 'strangers' here and do not have the kind of strong ties we would have in Lithuania. (e-mail interview on December 2-3, 2013) 


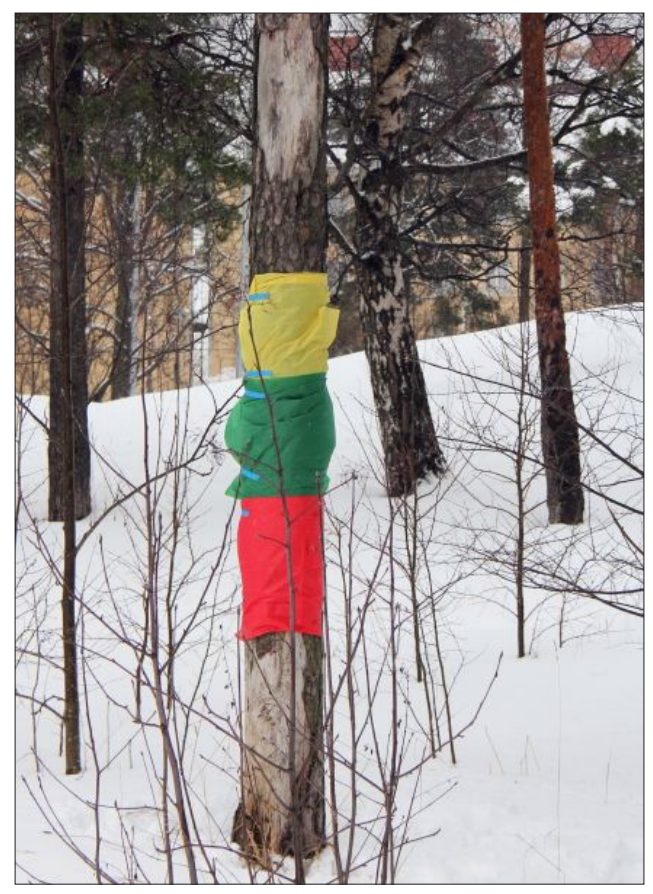

Figure 6a. Tree decorated with the colours of the Lithuanian flag.

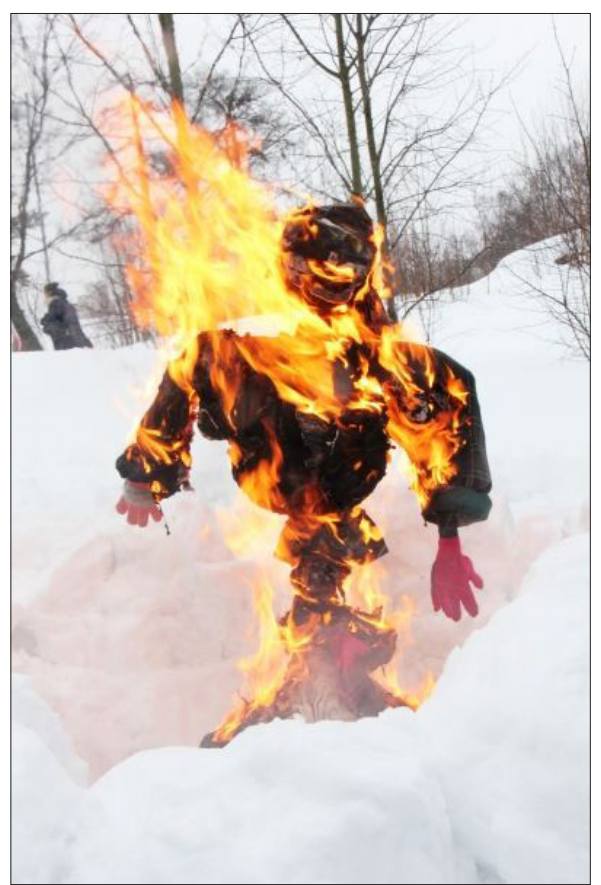

Figure 6b. Burning a mini-Moré. Finland.

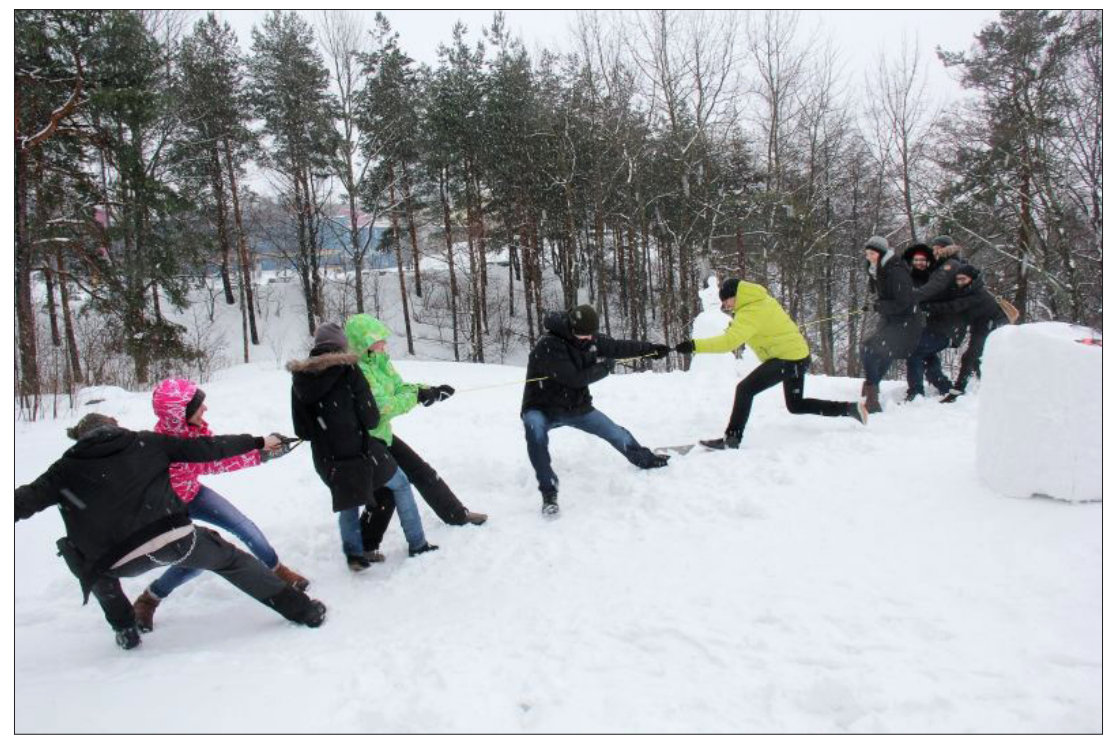

Figure 6c. Competition between Kanapinis and Lašininis teams. Photographs by Rūta Gjerde 2013. 
But there is no winter to be escorted or driven out in every foreign country. In some countries, like, for example, Greece, Užgavėnès is marked only by a general assembly of Lithuanians and the eating of pancakes (e-mail and telephone interviews on March 3, 2013, and December 3, 2013). Traditional foods can be a way for earning money. For example, a woman who immigrated from Lithuania Minor to Canada around 1950, popularised the tradition of eating stew on Pancake Tuesday among her fellow countrymen, using the money she had collected from the participants to support national organisations (Blockytè 2010: 258-259).

The central festival symbols include masked people, Moré, Kanapinis and Lašininis, and traditional Lithuanian dishes. It often takes only one traditional festival symbol to create, in the words of Jolanta Kuznecoviene, a deterritorialised ethnic cultural space (Kuznecovienè 2011: 93) that allows people to be safe and 'feel at home'.

\section{CONCLUSIONS}

The conducted research shows the transformations of the content of the Užgavenès festival over the course of time. The research reveals that the agrarian festival also had the features of a religious festival. The real effect of Christianity was not direct, but was connected with the structure of the Catholic ritual year. Užgavènès was the last day before the 46-day Lenten fast, which affected the festival mood and folk customs and provided a pretext during the Soviet occupation to call Užgavènès a religious festival.

Through the performance of many of the agricultural rituals by the youth and children, the festival acquired a recreational meaning. It also had such a meaning in the city where a pan-European recreational culture lacking any national character had formed. In the fourth decade of the 20th century Užgavènès acquired a national character. The Lithuanian festival, which began to spread also in the smaller cities, was created in Kaunas, the temporary capital of Lithuania, on the basis of Užgavènès traditions that existed in westLithuanian villages. This experience was also used in creating the socialist Užgavènès festival in Soviet Lithuania.

After the authorities had failed to create successful socialist festivals that had nothing in common with the traditions, it was decided to use the old festivals by giving them a 'socialist content'. The main accent of the Užgavėnès festival was shifted to the costumed procession. The costumed characters portrayed positive and negative figures that had to show the advantages of the new socialist life, 
fight against religion, praise good workers, and rebuke slackers. On the other hand, Užgavėnès, which maintained closer ties with the tradition, acquired the features of a ritual for driving out winter, and giving it the value of a festival marking a change in the seasons.

While discussing the creation of a Soviet ritual year in Lithuania and the meaning of the Užgavènès festival in this structure, several frequently intertwining meanings can be detected: the fight against religiousness, the objective of creating a socialist festival, the efforts to nurture Lithuanian festivals, and the encouraging of young people to take an interest in the ancient pre-Christian customs. This festival, which is treated in various ways, corresponded to the expectations of the gradually secularising general public throughout Soviet Lithuania.

Up until now, the status of Užgavènès as a festival for driving out winter and marking a change in the seasons has determined its fate and has even rendered meaning to it. Its spread in Lithuanian communities abroad has created a temporary deterritorialised Lithuanian ethnic cultural space and allowed people to feel 'at home' among their own kind and to maintain their ethnic identity.

\section{NOTES}

1 Shrove Tuesday is the traditional day of celebrating. However, many Lithuanians who are busy on this day, or due to other reasons, celebrate it on another - nonworking - day, which is close to this particular Tuesday. In the article, I have used the Lithuanian name Užgavenès to denote this festival.

${ }^{2}$ Lithuania consists of five ethnographic regions: Lithuania Minor and Samogitia in the west, Suvalkija in the southwest, Dzūkija in the southeast; Aukštaitija, the largest ethnographic region, covers the rest of the country.

3 The costumed figures embody representatives of ethnic groups, who in the agricultural community symbolised 'other' people who were engaged in non-agricultural professions (Anglickienè 2011: 10).

4 The Hungarians were known as physicians; in the processions they offer to check people's health and to sell them medicines.

5 The Jews were known as merchants; in the processions they offer to sell things to people.

6 A traditional Užgavènès costume portraying a very obese man who personifies satiety and symbolises the period from Christmas to Shrove Tuesday (Lith. mésedas).

7 A traditional Užgavėnès costume portraying a very thin man who personifies fasting and symbolises the period from Ash Wednesday to Easter. Kanapinis playfully battles Lašininis during the procession, eventually defeating him. 
8 A female figure, which is sometimes drowned or burnt during traditional Samogitian Užgavènès festivals.

9 In Lithuania, until the second half of the 20th century, it was not traditional to bake and eat pancakes on Shrove Tuesday.

${ }^{10}$ For example, 16,871 tickets were sold in $2011,16,343$ in $2012,16,477$ in 2013 , and 15,186 in 2014 (museum information as of 27.10.2014).

${ }^{11}$ During 1920-1939, Vilnius belonged to Poland and the capital of the Republic of Lithuania was moved to Kaunas.

${ }^{12}$ An analogy to the traditional Užgavènès character of Lašininis.

${ }^{13}$ Puńsk borders only on Dzūkija and Suvalkija ethnographic regions.

\section{ARCHIVAL SOURCES}

MFL - Manuscript fund of the Lithuanian Institute of History. Files 1272, 1318, 1319, $1325,1330,1334,1379-1388,1422,1442,1446-1452,1457,1505,1534-1536,1661$ 1664, 1693-1695, 1998-2000, 2075, 2219, 2309, 2328, 2334, 2340, 2341 (Žilvytis Šaknys' fieldwork materials from 1988 to 2009).

MFL, file 949. Mickevičius, Juozas. Užgavènès [Shrove Tuesday] (photographs in the file). MFL, photo negative No. 80111.

\section{MANUSCRIPT SOURCES}

Fieldwork materials from the years 2012 to 2013 in possession of the author.

\section{REFERENCES}

Andriuškevičius, Alfonsas 1969. Užgavėnès Grūšlaukyje. [Shrove Tuesday in Grūšlaukis.] Kraštotyra, pp. 224-227.

Anglickienè, Laima 2011. Kitataučių personažų transformacijos persirengimo papročiuose. [Transformations of Strangers' Masks in Lithuanian Feasts.] Tradicija ir dabartis, Vol. 6, pp. 9-24.

Balys, Jonas 1993. Lietuviu kalendorinès šventès. [Lithuanian Calendar Customs.] Vilnius: Mintis.

Bell, Catherine 1997. Ritual: Perspectives and Dimensions. New York \& Oxford: Oxford University Press.

Blinov 2013 = Blinov, Maksim. Grazhdanskaia kul'tura provintsial'nogo goroda v rannesovetskii period (na primere Izhevska). [Civil Culture of a Provincial Town in the Early Soviet Period (Izhevsk Case).] In: J. Mardosa (ed.) Šventès moderniame mieste / Festivals in the Modern City. Vilnius: Edukologija, pp. 127-137. 
Blockytè, Kristina 2010. Užgavènių šventès (Šiupinio vakaro) specifika Klaipėdos krašte. [The Specifics of the Shrove-Tide Celebrations (Stew Eve) in the Klaipeda Region.] Res Humanitariae VII, pp. 243-265. Available at http://www.ku.lt/leidykla/ files/2012/09/Visas_tekstas_2010_17.pdf, last accessed on February 3, 2015.

Budreckas, Petras 1936. Žemaitiški Užgaveniu papročiai Laisvès Alejjoje. [Samogitian Shrove Tuesday Customs in Laisvės Boulevard.] Newspaper Lietuvos aidas, No. 96, p. 4. Available at http://www.epaveldas.lt/vbspi/biRecord.do?biExemplarId=67120, last accessed on February 4, 2015.

Černeckis, Vincas 1961. Naujo gyvenimo tradicijos. [Traditions of a New Life.] Vilnius: Valstybinè politinès ir mokslinès literatūros leidykla.

Drożdż, Anna 2002. Komentarze do Polskiego Atlasu Etnograficznego. T. VII. Pomoc wzajemna: Wspótdziatanie społeczne $i$ pomoc sasiedzka. [Commentaries to the Polish Ethnographic Atlas. Vol. VII. Mutual Help: Social Cooperation and Neighbours' Help.] Wrocław \& Cieszyn: Polskie Towarzystwo Ludoznawcze \& Uniwersytet Śląski Filia w Cieszynie.

Jacėnaitè, Genovaitè 1992. Užgavėnės Užventyje. [Shrove Tuesday in Užventis.] Liaudies kultūra, No. 1, p. 11.

Jucevičius, Liudvikas Adomas 1959. Raštai. [Writings.] Vilnius: Valstybinė grožinès literatūros leidykla.

Krikščiūnienè, Inga 1992. Užgavėnès. [Shrove Tuesday.] Vilnius: Techlab.

Kudirka, Juozas 1992. Užgavenès. [Shrove Tuesday.] Vilnius: Mokslas.

Kudirka, Juozas 1996. Papročiai ir kaimo kultūra. [Customs and Folk Culture.] Vilnius: Lietuvos Respublikos žemès ūkio rūmai.

Kukharonak 2001 = Kukharonak, Tatstsiana. Maski v kalendarnoi obriadnosti Belorussii. [Masks in Calendar Rituals of Belarus.] Minsk: Uradzhai.

Kuznecovienè, Jolanta 2011. Išteritorinto identiteto alternatyvos: Lietuvių emigrantai Airijoje, Anglijoje, Ispanijoje ir Norvegijoje. [Deterritorialised Identity Alternatives: Lithuanian Emigrants in Ireland, UK, Spain, and Norway.] In: Vytis Čiubrinskas (comp.) Lietuviškas identitetas šiuolaikines emigracijos kontekstuose. [Lithuanian Identity in the Context of Modern-Day Emigration.] Kaunas: Vytauto Didžiojo universitetas, pp. 89-104.

Laučkaitè, Laima 2008. Vilniaus šventès ir pramogos prieš Pirmajį Pasaulinį karą. [Vilnius Festivals and Recreation before the First World War.] Naujasis židinysAidai, No. 11-12, pp. 468-475. Available at http://www.nzidinys.lt/files/various/ NZ-A\%202008\%20nr\%2011\%2012.pdf, last accessed on February 4, 2015.

Merkienė, Irena Regina 2011. Kalendorinių švenčių apeigos. [Rituals in Calendar Festivals.] In: Vida Savoniakaitè (ed.) Lietuvos etnologijos ir antropologijos enciklopedija. [An Encyclopaedia of Lithuanian Ethnology and Anthropology.] Vilnius: LII leidykla, pp. 173-174.

Mickevičius, Juozas 2008. Tévu ir proteviu žemé: I knyga. [The Land of Parents and Grandparents: 1st Book.] Vilnius: Regionų kultūrinių iniciatyvų centras.

Olechnovičienè, Vida 2008. Lietuvos liaudies buities muziejus: Kalendorinių švenčių papročiai. Tradicijos atgaja. [Open Air Museum of Lithuania: Customs of Calendar Festivals. Refreshing of the Tradition.] Gimtasai kraštas, Vol. 1, pp. 120-126. Available at http://www.ziemgala.lt/lt/metrastis-gimtasai-krastas/gimtasaikrastas-2008/lietuvos-liaudies-buities-muziejus-kalendoriniu-svenciu-paprociaitradicijos-atgaja, last accessed on February 4, 2015. 
Olupe, Edīte 1992. Latviešu gadskārtu ieražas. [Latvian Calendar Customs.] Rīga: Avots. Petrošienè, Lina 2013. Užgavėnių šventès atgarsiai lietuviškoje XX a. pirmosios pusès periodikoje: kaip šventè miestiečiai? [Glimpses of the Shrovetide Holiday in the Early 20th Century Lithuanian Press: How Townspeople Celebrated It.] Istorija, Vol. 2 (90), pp. 14-21. Available at http://www.istorijoszurnalas.lt/images/stories/ Istorija_90/Istorija90.pdf, last accessed on February 4, 2015.

Šaknys, Žilvytis 1996. Jaunimo brandos apeigos Lietuvoje: XIX a. pabaigoje - XX a. pirmojoje puseje. [Youth's Initiation Rites in Lithuania: End of the 19th - 1st Half of the 20th Centuries.] Vilnius: Pradai.

Šaknys, Žilvytis 2001a. Kalendoriniai ir darbo papročiai Lietuvoje XIX a. pabaigoje $\mathrm{XX}$ a. pirmoje pusejje: Jaunimo vakarèliai. [Lithuanian Calendar and Work Customs in the Late 19th - 1st Half of the 20th Centuries: Youth Parties.] Vilnius: Diemedžio leidykla.

Šaknys, Žilvytis 2001b. Pietryčių Latvijos lietuviai: kultūra, etniškumas ir bendraamžiu bendrija. [Lithuanians in Southeast Latvia: Culture, Ethnicity and the Community of Peers.] Lietuvos etnologija: Socialinès antropologijos ir etnologijos studijos, Vol. 1 (10), pp. 231-250. Available at http://etalpykla.lituanistikadb.lt/fedora/ objects/LT-LDB-0001:J.04 2001 1367158523539/datastreams/DS.002.0.01. ARTIC/content, last accessed on February 4, 2015.

Šaknys, Žilvytis 2007. Jaunimo iniciaciniai ir kalendoriniai papročiai. [Youth Initiation and Calendar Customs.] In: R. Paukštytė-Šaknienė \& V. Savoniakaitė \& Ž. Šaknys \& I. Šidiškienè (eds.) Lietuvos kultūra. Aukštaitijos papročiai. [Lithuanian Culture: Traditions of Aukštaitija.] Vilnius: LII leidykla, pp. 65-116.

Šaknys, Žilvytis 2009. Jaunimo iniciaciniai ir kalendoriniai papročiai. [Youth Initiation and Calendar Customs.] In: R. Paukštytè-Šaknienè \& V. Savoniakaitè \& Ž. Šaknys \& I. Šidiškienè (eds.) Lietuvos kultūra: Dzūkijos ir Suvalkijos papročiai. [Lithuanian Culture: Traditions of Dzūkija and Suvalkija.] Vilnius: LII leidykla, pp. 64-110.

Šaknys, Žilvytis 2012. Jaunimo iniciaciniai ir kalendoriniai papročiai. [Youth Initiation and Calendar Customs.] In: R. Paukštytė-Šaknienè \& V. Savoniakaitè \& Ž. Šaknys \& I. Šidiškienè (eds.) Lietuvos kultūra: Mažosios Lietuvos ir Žemaitijos papročiai. [Lithuanian Culture: Traditions of Lithuania Minor and Samogitia.] Vilnius: LII leidykla, pp. 77-135.

Šaknys, Žilvytis 2013. Ritualiniai metai šiuolaikinèje Lietuvoje: Miesto ir kaimo perspektyvos. [Ritual Year in Contemporary Lithuania: Prospects of City and Province.] In: J. Mardosa (ed.) Šventes moderniame mieste / Festivals in the Modern City. Vilnius: Edukologija, pp. 100-109.

Šimkutè, Dalia 2012. Kazimiera Vellemaa: "Dabar jau mano šaknys ten, Estijoje". [Kazimiera Vellemaa: "Now my roots are there in Estonia".] Newspaper Vakarine Palanga, November 19. Available at http://www.vakarinepalanga.lt/ lt/archyvas/?id=3577, last accessed on February 4, 2015.

Skrodenis, Stasys 2010. Folkloras ir gyvenimas. [Folklore and Life.] Vilnius: Vilniaus pedagoginio universiteto leidykla.

Užgavėnès 1959 = Užgavènès - žiemos šventè. [Shrove Tuesday - Winter Festival.] Metodinè medžiaga. Vilnius: LTSR kultūros ministerija \& Respublikiniai liaudies kūrybos namai. 
Vaicekauskas, Arūnas 2005. Lietuvių žiemos šventès: Bendruomeninès kalendorinio ciklo apeigos XIX a. pab. - XX a. pr. [Lithuanian Winter Festivals: The Rites of the Community Calendar Cycle in the Late 19th - Early 20th Centuries.] Kaunas: VDU leidykla.

Vaicekauskas, Arūnas 2010. Lietuvių Užgavènès: Nacionalinio tapatumo linkme? [Lithuanian Shrovetide Customs: Towards National Identity?] Liaudies kultūra, No. 2, pp. 23-29. Available at http://www.llkc.lt/index.php?1532573788, last accessed on February 4, 2015.

Vaicekauskas, Arūnas 2013. Carnival Culture in the Baltic Region: New Tendencies. In: Arūnas Vaicekauskas (ed.) The Power of the Mask: The Ritual Year 5. Kaunas: Vytautas Magnus University, pp. 48-54.

Vaicekauskienè, Aldona 1996a. Iš Punsko licejjaus LVKD būrelio veiklos. [From Puńsk Lyceum LVKD Circle Activities.] In: M. Černelienè (ed.) Punsko Kovo 11-osios lietuviu gimnazija. [Gymnasium of the 11th March in Puńsk.] Punskas: Aušra, pp. 177-182.

Vaicekauskienè, Aldona 1996b. Gimnazijos etnografinis būrelis. [Gymnasium Ethnographic Club.] In: Punsko Kovo11-osios gimnazija. [Gymnasium of the 11th March in Puńsk.] Punskas: Aušra, pp. 156-162.

Van Ginkel, Rob. 2007. Celebrating Localism: The Festive Articulation of Texel's Identity. In: Peter Jan Margry \& Herman Roodenburg (eds.) Reframing Dutch Culture: Between Otherness and Authenticity. Wiltshire: Ashgate, pp. 37-57.

Vèlius, Norbertas (ed.) 1996. Baltu religijos ir mitologijos šaltiniai. [Sources of Baltic Religion and Mythology.] Vol. 1. Vilnius: Mokslo ir enciklopedijų leidybos institutas.

Vyšniauskaitè, Angelè 1964. Naujų tarybinių papročių formavimasis. [The Formation of New Soviet Customs.] In: Lietuvių etnografijos bruožai. [Lithuanian Ethnography.] Vilnius: Valstybinè politinès ir mokslinès literatūros leidykla, pp. 551-567.

Znamierowska-Prüfferowa, Maria 2009. Vilnius, Miestas arčiausia širdies. [Vilnius: The City Closest to my Heart.] Vilnius: Alma littera.

\section{INTERNET SOURCES}

Užgavėnès Vilniuje! Renginių programa. [Shrove Tuesday in Vilnius! Event programme.] Available at http://www.makalius.lt/kelioniu-naujienos/uzgavenes-vilniuje-renginiuprograma, last accessed on January 23, 2015.

Prezidentė D. Grybauskaitè: Užgavėnès tai - kvietimas kiekvienam įveikti negeroves ir atsinaujinti. [President D. Grybauskaitė: Shrove Tuesday is an invitation to each of us to overcome problems and to renew ourselves.] Available at http://alkas. lt/2013/02/12/prezidente-d-grybauskaite-uzgavenes-tai-kvietimas-kiekvienamiveikti-negeroves-ir-atsinaujinti-video/, last accessed on February 3, 2015.

Rusijos Lietuvių Bendruomenių Sajunga. [Union of Russian Lithuanian Communities.] Available at http://www3.lrs.lt/pls/inter/w5_show?p_r=509\&p_d=7286\&p_k=1, last accessed on February 3, 2015.

Lietuvių Bendruomenè Švedijoje. [Lithuanian Community in Sweden.] Available at http://www.lietuviai.se/index.php?page=saule, last accessed on February 3, 2015. 